\title{
Why Bail-In Securities Are Fool's Gold
}

\section{Avinash D. Persaud}

Avinash D. Persaud is nonresident senior fellow at the Peterson Institute for International Economics and emeritus professor at Gresham College, UK.

(C) Peterson Institute for International Economics. All rights reserved.

Bailouts and bail-ins of failing financial institutions have been hotly disputed in the global financial crisis of the last five years. At the height of the crisis, several failing banks were bailed out with taxpayer money so they could service their debts, but as public outrage mounts, policymakers are increasingly looking at bailing in these institutions before using taxpayer funds. Bail-ins, also called haircuts, require the troubled institution's creditors to write off some of the debt or agree to a restructuring of the debt, which reduces their holdings. The public has demanded the imposition of these costs on creditors and bondholders, arguing that if bad lending as well as bad borrowing went unpunished it would be encouraged. Additionally, the yawning fiscal deficits that have followed bailouts have led to unpopular fiscal retrenchment.

Consequently, eliminating bailouts has become a political imperative on both sides of the Atlantic. The clear intention of the Dodd-Frank Act (2010) in the United States was to end taxpayer bailouts through more bail-ins. The European Union's Bank Recovery and Resolution Directive (BRRD), due to come into force in January 2015, requires creditor bail-in before public funds can be accessed. ${ }^{1}$ Bail-ins and creditor haircuts have long been a feature of resolutions and recapitalizations when banks have become, or are on the verge of becoming, "gone" concerns. This time the public outcry against bailouts has also led to the development of something new-the auto-

1. European Stability Mechanism, Guideline on Financial Assistance for the Recapitalisation of Financial Institutions, 2013. matic bail-in of creditors of institutions that are still going concerns. ${ }^{2}$ This mechanism and its attendant instruments are the focus of this Policy Brief.

The Financial Stability Board and national regulatorsincluding the US Federal Reserve Board and the European Central Bank (ECB) —are formalizing rules requiring the 30 globally systemically important banks (GSIBs) to hold an additional layer of capital. Estimates range from 4 to 7 percent of risk-weighted capital or approximately $\$ 1.2$ trillion globally or $\$ 250$ billion in the United States and more in Europe. A bank's losses would be met by this additional buffer first before the minimum capital adequacy level is touched. To put the size of this new buffer into context, between 2009 and 2012, the 16 largest US banks raised just $\$ 24$ billion of new equity capital and the 35 largest banks in Europe raised only $\$ 23$ billion. ${ }^{3}$ But the proposal is that this additional layer of capital need not be in the form of equity or retained earnings. We may be witnessing a political tradeoff where bankers give in to the substantially higher overall capital requirements demanded by politicians if part of this additional capital is in instruments that, compared with issuing more equity, are cheaper ${ }^{4}$ and do not dilute the bankers' control and pay in the good times. These bail-in securities, commonly known as cocos, ${ }^{5}$ convert into equity once a bank's capital falls below a preannounced level. Even before the ink is dry on these proposals, banks have started to issue cocos and the market has quickly grown to a capitalization of $\$ 150$ billion.

The case for bail-in securities is that bailouts create "moral hazard," i.e., they encourage reckless lending by banks in the secure knowledge of a rescue if desperate times ensued. Bailouts also allow depositors, creditors, and investors to relax their monitoring of banks knowing that taxpayers will foot the bill if things fell apart. Many see both behaviors as critical in perpetu-

2. See Basel Committee on Banking Supervision (2011) and Avgouleas, Goodhart, and Schoenmaker (2013).

3. Data are from the Bank for International Settlements.

4. Or at least appear cheaper from the perspective of the bankers making the decision. See Admati et al. (2011).

5. Coco stands for contingent, convertible capital instruments. 
ating boom-bust cycles. ${ }^{6}$ In fixed exchange rate regimes, such as the eurozone, there is the added potential of a "doom-loop," where increased public debts and sovereign credit downgrades undermine the remaining healthy banks that hold much of their assets in government securities (Avgouleas and Goodhart 2014). Higher public debts in Europe and elsewhere, as a result of bailouts, have also led to cuts in safety nets to the most vulnerable and in public investment.

\section{Bail-in securities do not make sense in the more common and intractable case where}

\section{many banks get into trouble at roughly the \\ same time as the assets they own go bad.}

The case of moral hazard may be overstated. An important element of financial crisis is commonly considered safe assets, like housing, becoming risky, not starting off as risky, but the focus of this Policy Brief is on how these new bail-in instruments fare when clouds first appear on the horizon. Bail-in securities may make sense for an idiosyncratic bank failure-like the 1995 collapse of Baring Brothers, which was the result of a single rogue trader. But they do not make sense in the more common and intractable case where many banks get into trouble at roughly the same time as the assets they own go bad. On such occasions these securities, which may also have encouraged excessive lending, either will inappropriately shift the burden of bank resolution on to ordinary pensioners or, if held by others, will bring forward and spread a crisis. Either way they will probably end up costing taxpayers no less and maybe more. In this regard, fool's gold is an apt description. ${ }^{7}$ Fool's gold has a metallic lustre that gives it a superficial resemblance to gold. However, it is an iron sulphide, one of the ancient uses of which was to spark fires. Either we need real gold-more equity capital—or not. Fool's gold is no alternative.

\section{WHAT ARE GOING-CONCERN BAIL-IN SECURITIES?}

Banks are required to hold a minimum amount of capital-assets able to absorb a loss. They generally can't meet permanent losses by borrowing, for instance, because it would need to have the resources to repay those loans with interest. Bank capital is primarily made up of retained earnings and the sale of equity

6. For further discussion, see Tucker (2014).

7. I first used this metaphor in "Bail-Ins Are No Better than Fool's Gold," Financial Times, October 13, 2013. held in near-cash instruments. The minimum amount of capital held by internationally important banks is set under the Basel Accord and is a ratio of the bank's risk-weighted assets. The idea is that the riskier the assets the more capital banks need to hold. ${ }^{8}$ The 30 GSIBs hold approximately $\$ 47$ trillion of assets, $\$ 18$ trillion of risk-weighted assets, and $\$ 2.5$ trillion of capital. ${ }^{9}$ Many issues surround this framework, such as the assessment of what is safe and risky and what requires social insurance, but further discussion of these is outside the scope of this Policy Brief.

When a going concern's capital falls below a preannounced ratio of its risk-weighted assets, bail-in securities automatically convert into more equity to absorb the concern's losses. Cocos are bonds that pay a coupon in good times and convert into equity that could be lost completely without any recourse in bad times. This new equity injection automatically dilutes existing shareholders. The range of instruments that have a similar effect goes beyond cocos and includes other hybrids (financial instruments bearing characteristics of both debt and equity) or wipeout bonds. ${ }^{10}$

One of the critical issues for cocos and similar instruments is the point at which they automatically convert from debt-like to equity (i.e., the trigger level). ${ }^{11}$ Too low a trigger and in effect the instrument converts directly into a loss. Too high a number and it may give the false impression that the bank is about to topple over. Banks fear the latter more than the former. In periods of financial stress, financial markets quickly become febrile rumor mills where expectations-right or wrong-become self-fulfilling. If a bank's counterparties are reluctant to extend short-term advances it is quickly done for. Most of the early cocos had low trigger levels. ${ }^{12}$ To offset the tendency to set trigger levels too low, some newer instruments have dual triggers, with the first trigger leading not to conversion but suspension of the coupon payment.

Although the picture is still emerging, it appears that regulators at the Financial Stability Board are progressing towards an international agreement that by 2019 the 30 GSIBs should carry total loss absorbing capital (TLAC) of around 16 to 20 percent

8. For an up-to-date discussion on the risk-weighted assets regime, see Basel Committee on Banking Supervision (2013).

9. Data are from the Bank for International Settlements, 2014.

10. On August 2, 2013, Credit Suisse issued a ten-year $\$ 2.5$ billion "wipeout bond" with a 6.5 percent coupon. Unlike some cocos, where bonds automatically convert into equity once a bank's capital falls below a certain threshold, this bond has a "sudden death" if Credit Suisse's capital falls below 5 percent of its risk-weighted assets or if a national regulator deems it is near breach of its tier one capital ratio. See Financial Times, August 2, 2013.

11. See Calomiris and Herring (2012).

12. Under Basel III, the minimum trigger level in terms of risk-weighted assets required for a coco to qualify as additional tier 1 capital is 5.125 percent of risk-weighted assets and early issues ahead of recent plans were set at that level. 
of risk-weighted assets, but when factoring in other buffers this will effectively be 21 to 25 percent. Critically, only part of that will need to be in the form of equity or retained earnings. The rest will be in the form of bail-in securities, because for a banker issuing equity is more expensive than debt. The 30 GSIBs would require over $\$ 1$ trillion of new bail-in securities.

\section{When a going concern's capital falls below a preannounced ratio of its risk-weighted assets, bail-in securities automatically convert into more equity} to absorb the concern's losses.

The market for bail-in securities has already grown from virtually nothing in 2010 to a cumulative issuance of approximately $\$ 150$ billion today, despite the fundamental uncertainty about regulations regarding the amount of capital required and the features of eligible bail-in securities. This growth is perhaps a testament to the hunger for assets and yield in the marketplace today. Credit Agricole's coco issued in February 2014, which offered a 7.8 percent coupon, generated $\$ 25$ billion of orders chasing a $\$ 1.75$ billion issue. Since then the Credit Suisse index of coco yields has fallen to 6.0 percent. The trend line is straight, where each year more cocos are being issued than in the previous, suggesting that a target of $\$ 1.2$ trillion may be possible if raised over several years, though the proposed 2019 target is tight. By the end of 2014, still ahead of formal agreement on what constitutes an eligible bail-in security, an estimated $\$ 85$ billion worth of cocos will have been issued. Recent issuers include Banco Bilbao Vizcaya Argentaria, Barclays, UBS, Crédit Agricole, SNS Reaal, Société Générale, and KBC Bank. Deutsche Bank and HSBC are reportedly debating issues on the order of $\$ 6$ billion. Approximately 80 percent of the issuance has been from European banks (including those headquartered in the United Kingdom and Switzerland). ${ }^{13}$ In the absence of the scrutiny that will come when one of these instruments is "converted," there is little information on who is buying. Early indications suggest it is investors focused on short-term gains, namely retail investors, private banks, and hedge funds, ${ }^{14}$ not the buyers regulators want.

13. BIS Quarterly Review, June 2013.

14. Ibid.
WHY PENSION FUNDS AND LIFE INSURANCE COMPANIES SHOULD NOT OWN THESE SECURITIES

Regulators are particularly keen that banks not hold cocos. The banking system is more "systemic" than almost any other because of its unusual degree of interconnectivity: One bank's loan is another's deposit. If banks held the bail-in securities of other banks, trouble at one bank would instantly spread to other banks. Interconnectivity would be reinforced, not dispersed. This interconnectivity would also exist if the holders received a significant amount of their funding from banks, such as leveraged special investment vehicles, hedge funds, or private equity firms. Regulators say that they want long-term holders of these instruments. It is likely that they will propose that in order to count towards TLAC, a bail-in security must have a maturity of at least 12 months, possibly longer, with a view to attracting long-term investors to own these assets. Banks have followed suit and many of the issued bonds have maturities of 5 to 10 years.

Long-term holders are primarily pension funds and life insurance companies as they have the long-term liabilities. Many throw sovereign wealth funds into the mix; they did step up to the table in 2007 and 2008 in a few high-profile bank capital raisings. However, once defined as funds that are not backed with short-term liabilities like foreign exchange reserves, they are not as large in aggregate as many think. Cumulative assets are not much more than $\$ 6$ trillion. Pension fund assets in advanced countries are close to $\$ 22$ trillion. While this appears to dwarf the potential size of the bail-in security market, most of these assets are concentrated in the three countries that rely on private rather than public pension provision (United States, United Kingdom, and the Netherlands) and where a fair portion of the assets are in annuity programs with little capacity for investment risk. In countries such as Germany, France, Italy, Spain, Belgium, and Portugal, there is a severe mismatch between the proportion of risk-weighted assets of banks and the proportion of pension assets held there.

There are other, major problems with pushing these instruments on to pension funds and life insurance firms. A key danger is that taxpayers would be saved by pushing pensioners under the bus. If a crisis has not been prevented, it is unlikely that the direct and indirect consequences of delivering a loss to pensioners are lower, and more fairly distributed, than giving taxpayers a future liability. The opposite is far more likely to be the case. Indeed, it is interesting that in 2014 the United Kingdom's new Financial Conduct Authority used its consumer protection powers for the first time in suspending the sale of cocos to retail investors on the grounds that the instruments were "highly complex" and "un- 
likely to be appropriate for the mass retail market." The authority also stated that "there is growing concern that even professional investors may struggle to evaluate and price cocos properly." 15 If pension funds suffered losses on cocos, taxpayers would very likely be pressured into bailing them out. Given the greater fragmentation of the savings markets such a bailout will probably be even more complicated, messy, and politically sensitive than bailing out a handful of banking institutions.

\section{From an investment and economic perspective these are the wrong type of instruments for pensioners} and life insurers to own.

Another problem is that from an investment and economic perspective these are the wrong type of instruments for pensioners and life insurers to own. Financial instruments offer returns above the risk-free rate as compensation for different risks. The principal investment risks are credit, liquidity, and market risks. They are identifiably separate types of risks because each must be hedged differently. Distinct investors, courtesy of their unique liabilities, have innate abilities to hedge certain risks and natural inabilities to hedge others. The right economic and investment strategy for an investor is to hold those risks for which they have a natural ability to hedge and to rid themselves of risks that they cannot hedge. ${ }^{16}$ That strategy will lead pension funds and life insurance companies away from bail-in securities, unless the authorities attract them in some other way. It also suggests that their current reluctance to buy them is deliberate and not a result of unfamiliarity.

Liquidity risk is the risk that if one has to sell an asset tomorrow it will fetch a far lower price than if one could afford the time to wait to find the particular buyer. To hedge liquidity risks one must have time to wait-perhaps through long-term funding or the long-term liabilities that pension funds and life insurance companies have. But having time does not help to hedge credit risks. The longer a credit risk is held the more time there is for it to blow up. Being required to hold a General Motors bond for one day carries little risk. Being required to hold it for 25 years carries significantly greater risk. Credit risk is best hedged by diversifying across a wide range of credit risks

15. Anna Gelpern of Georgetown University and the Peterson Institute for International Economics alerted me to this interesting announcement, which points to a lack of reflection and co-ordination between regulators over who they expect to hold the very instruments they consider so important to systemic resilience.

16. For a further discussion, see Warwick Commission (2009) and Persaud (2014). and actively managing the spread of risk-in the way that a bank or a credit hedge fund can do far more easily than a traditional pension fund. The right instruments for institutions with long-term liabilities, like pension funds and life insurance, are instruments offering a higher return because they are illiquid rather than because they carry substantial credit risk. Examples of these instruments include infrastructure bonds, (especially where there are guarantees or hedges on the construction risk and market risk), asset-backed securities, and real estate development - the exact type of assets they have historically purchased.

From a private investment perspective, bail-in securities are best held by investors able to diversify and monitor a wide range of liquid credit risks, such as hedge funds. It should be no surprise that they appear to be the ones currently buying them. Encouraging pension funds and life insurance companies to follow would not be in their best interests.

\section{ROLE OF HOMOGENEITY IN AGGRAVATING LIQUIDITY CRISES}

If, in a liquidity crisis, the price of a credit instrument falls sharply_not because it is no longer performing but because the market is so spooked by a background of turmoil that there is no liquidity in the asset class - then it makes sense for institutions who can comfortably own liquidity risk, like pension funds and life insurance companies, to buy them at that point. They should then keep them until their price has recovered and the greater part of their future return no longer reflects a liquidity risk but a credit risk. Allowing pension funds and insurance companies to do that not only makes good sense for them-they are earning a return for taking a risk they have a natural ability to hedge-but it also makes for a more resilient financial system.

Life insurance companies complain that regulators of savings institutions make it hard for them to do that through regulatory requirements to hold certain assets, mark their assets to market prices, and adhere to short-term measures of solvency. It would also be hard-usually for internal reasons-for them to buy bail-in securities when they are cheap if they had previously owned them at a time when they were expensive. If they had bought bail-in securities during the good times and suffered an unanticipated loss later, regulatory and internal pressures (investment losses tend to trigger regret rather than a desire to find bargains) would conspire to reduce their appetite to purchase the better valued of these instruments just when the market most needs buyers and differentiation.

The regulation of long-term savings institutions is a subject for another Policy Brief, though I will make the observation here that bank regulators appear to be putting the safety of banks into the hands of a different part of the financial sector- 
long-term savings institutions-not regulated by them and without much coordination with that sector's regulator. But there is an important point here on systemic resilience that will further inform this discussion on what kind of instruments and behavior would reduce the scale of financial crises and the attendant need for taxpayer support. Financial sector liquidity is about diversity not size. A market with only two players, where one player wants to buy whenever the other wants to sell, perhaps because one has short-term liabilities and focus and the other long-term liabilities and focus, is more liquid than one with a thousand players who, because they all use the same model of value and risk, want to buy or sell assets at the same time. Homogeneity of behavior is the route to liquidity crises (Persaud 2000). Heterogeneity creates resilience. ${ }^{17}$

To limit the economic disruption and costs of a financial crisis the forces of homogenous behavior must be tempered and the sources of heterogeneity encouraged. Observers of economic or financial cycles would recognize this as the need for instruments or investment behavior that counters the procyclicality of finance (Brunnermeier et al. 2009). A simple test of whether a new policy or instrument will help deal with a liquidity crisis is whether it will moderate the collective enthusiasm to buy assets during a boom or the crowd mania to sell them during a crisis. The dynamics of financial markets suggest that bail-in securities will fail this test.

Short-term investors, such as hedge funds, who buy these instruments do so today and will do so in the future because they see no near-term risk of a bail-in. Their investment philosophy will be that in the long run you need to be out or you are dead. The longer their belief that short-term risks are low is validated, the more confident they will get and the more they will want to own these instruments, sending their yields lower. The more these yields fall, the more the banks will be encouraged to issue more of these securities, enabling them to lend more. Incidentally, because they are short-term in focus they will not, as it was hoped of holders of these instruments, invest in monitoring long-term developments and emerging concentrations of risk. They will assume that they are not holding these instruments long enough for it to matter to them and anyway someone else is doing that. ${ }^{18}$ It is therefore unlikely that these instruments would temper bank lending prior to a crash.

If prior to the global financial crisis we had a "going concern, total loss absorbing capital limit" of 25 percent of riskweighted assets, and half of that capital was in bail-in securi-

17. This resonates with our understanding of strength in nonfinancial systems like urban traffic or civil engineering. The unusually strong tensile strength per weight of bamboo and the webs of spiders is based not on their size but the complex nature of their internal structure.

18. The free-riding of short-term players on the monitoring and risk-management role of long-term investors cries out for some kind of "Pigouvian" intervention. ties, banks may have had even more assets on their books-not less. Confidence in financial markets generally comes in only two flavors: high or low. In the United States, over the past 15 years, the Federal Deposit Insurance Corporation (FDIC) has closed 532 banks - an average of 35 each year. Yet in 2003 only three banks were closed and in 2004 four. None were closed in 2005 and 2006. During the four years before the global financial crisis, when confidence was riding high, the yields on subprime mortgages were low, falling within 1.0 percent of AAA corporate bonds in 2004. It wasn't just short-term financial participants who were overconfident. Prior to 2007, Financial Stability Reviews at central banks regularly supported the notion that the new risk management techniques and bumper estimates of bank capital suggested banks had never been so safe and the search for systemic risk was concentrated elsewhere. It is contrary to the lessons of history to suppose that if bail-in securities were around then, their yields would have constrained banks from issuing more and lending more. Even today, when the economy is far from free of the clutches of the global financial crisis, bail-in yields at close to 6.0 percent ${ }^{19}$ are below long-run average equity returns.

When an event changes perceptions of risk, short-term investors in these bail-in securities will trample over each other to reach the exit before bail-in (Ubide 2008). These investors are not interested in hanging on, not just for reasons of potential losses but because a bail-in is not an eventuality they have the institutional capacity to manage. Funds that trade in liquid debt securities cannot easily become owners of illiquid bank equity. As they form a disorderly queue at the exit, the price of these securities will collapse, triggering a series of contagious mechanisms. We have seen these before, notably in the Asian financial crisis between 1997 and 1999, during the first, creditderivative phase of the global financial crisis between 2007 and 2008, and to some extent during the October 1998 Long-Term Capital Management (LTCM) crisis.

Faced with collapsing prices, and declining confidence, the rating agencies will downgrade bail-in securities. More stoic holders of bail-in securities who had resisted the urge to sell in the first wave will now be forced to sell as a result of investment mandates limiting the holdings of low-rated instruments. If the size of the market were $\$ 1.2$ trillion then it would be significant enough. However, there will be wider knock-on effects where these instruments are being used as collateral for other instruments or where their prices are used to price other, less liquid, assets. Hedge fund clients will bolt for the exit, forcing hedge funds to raise liquidity by selling otherwise unconnected assets. These indirect effects will give an impression that strong, hidden undercurrents are driving financial markets, which will cause aggregate uncertainty to rise, triggering a general risk aver-

19. Yield in September 2014 of Credit Suisse's index of cocos. 
sion and further liquidation of assets. There are many avenues through which the correlation of asset prices tends towards 1 during a period of stress. Collapsing asset prices will undermine the position of banks. Bail-in securities will bring forward and spread a crisis, not snuff it out.

As recently as February 2013, long after policymakers had insisted that the time for bailouts was over, the Dutch government decided to nationalize SNS Reaal and spend \$5 billion paying off senior creditors, protecting depositors in full, and cleaning up the bank. ${ }^{20}$ The Dutch finance minister said that this was necessary because not doing so would have posed a "serious and immediate threat...to the stability of the financial system."21 A similar approach was taken in August 2014 in the rescue of the Portuguese Banco Espirito Santo, even though there was a good case to let it fail due to the unusual and precarious situation the bank was put in by its controlling shareholders. ${ }^{22}$

Supporters of cocos argue that Europe required only another $€ 150$ billion of capital to offset bank losses, and bail-ins of this large but manageable sum would not be destabilizing. This is how it might look long after the embers of a financial crisis have cooled. But in the middle of a crisis, when bail-ins would be triggered, speculation of potential losses is many times greater than the realized losses once the system has been stabilized. At the time of Lehman's default it was widely reported in the press that losses could range from $\$ 270$ billion to $\$ 360$ billion as it was feared that many counterparties would not honor their side of derivative contracts. When the dust settles, counterparties survive, and the administrator and lawyers have done their chasing, the net payout will be just $\$ 6$ billion. ${ }^{23} \mathrm{It}$ would be wrong to conclude that all would have been fine if only there were another $\$ 6$ billion of capital.

20. Simon Johnson of MIT and the Peterson Institute for International Economics alerted me to this and other recent cases where policymakers chose not to bail in despite their earlier "promises" to do so more readily.

21. Quoted in "Dutch Government Takes Control of SNS Reaal," New York Times, February 1, 2013.

22. Banco Espirito Santo would appear to be precisely the kind of bank that the authorities would want to make an example of. The Espirito Santo family controlled the bank with little capital and much leverage through a complex layering of shareholdings held in offshore entities, family members proliferated in its management, allegations of cronyism were rife, especially in dealings in Portugal's former colony, Angola, and when the economic climate called for caution they invested in assets that didn't perform and funded themselves by stuffing the clients of one of their investment subsidiaries with the debt of their banking subsidiaries. The authorities have removed Ricardo Espirito Santo Salgado's passport and may well charge the bank's former head with fraud, but the decision to bail out the senior creditors and depositors underscores the practical, financial, psychological, political, and moral complexities of bail-ins even when they are part of a gone concern.

23. According to the International Swaps and Derivatives Association (ISDA) and the Depository Trust and Clearing Corporation (DTCC).

\section{IN CONCLUSION}

Bailouts risk encouraging reckless bankers and creditors and depositors who take their eyes off the ball (Huertas 2013). The global financial crisis has also powerfully illustrated how the socialization of risks can hobble policymakers from fully responding to the economic consequences of a financial crisis and can have seriously adverse distributional consequences. But the market dynamics that deliver financial crises cannot easily be adjusted to deliver bank resolutions that are free from recourse to taxpayers or severely adverse economic consequences. Credit economies are founded on confidence and there are no easy market mechanisms to recover from the disruption of that confidence (Jaffee and Russell 1997).

\section{Bail-in securities are not the silver bullet...}

\section{they will likely make matters worse. If}

\section{more gold plating of bank capital is what is}

\section{required, then this fool's gold will not do.}

Bail-in securities will help to address idiosyncratic bank failures where the circumstances are unique to one institution, confidence in the system is not at risk, and the scope for contagion is limited. But authorities are already quite good at resolving these individual gone concerns, often with the help of some creditor bail-in or haircut. In the United States, the FDIC has been doing so routinely and quite effectively for decades. In the United Kingdom, the oft-quoted example is the tidy wind up by the Bank of England of Barings Bank in 1995 after Nick Lesson's trading bets on the Nikkei 225 futures rid the bank of all its capital. ${ }^{24}$ The circumstances that the authorities are much less good at resolving are those where many banks run into trouble around the same time. It is in these situations that bail-in securities are likely to make matters worse not better.

Regulators envisage bail-in securities will be bought and held by long-term investors like pension funds or life insurance companies. But these are the wrong kinds of assets for investors with long-term liabilities. Regulators should know better. Pension funds and insurance companies need assets that provide higher yields as compensation for liquidity risk not credit risk. Credit risk, like that embedded in bail-in securities, is a risk that rises with time and is best held by investors with access to a wide

24. The collapse of Barings is frequently quoted because it was one of the world's oldest merchant banks and its 1995 collapse was in sharp contrast to its bailout in 1890, organized by the then Bank of England governor William Lidderdale. The 1890 bailout stopped the "Panic of 1890," which had been triggered by concerns over a potential Argentine default becoming more systemic. The 1995 collapse caused no widespread panic. 
range of credit risks that they actively diversify and manage over the short term and not by investors who buy and hold for a long time. If regulators prohibit banks and retail investors from holding these instruments they will be held by short-term, leveraged investors like hedge funds. This appears to be what is already happening with institutional investors staying away and hedge funds chasing the extra basis points. But if hedge funds own a $\$ 1$ trillion plus bank bail-in securities market, it will likely lead to a crisis being brought forward and spreading.

A test of whether a new policy or instrument will help deal with a liquidity crisis is whether it will moderate the collective enthusiasm to buy assets during the prior boom or to sell them during the subsequent crisis. Bail-in securities held by hedge funds or other short-term, leveraged institutions would fail this test. During the boom years when short-term risks appear low and this assessment is repeatedly validated over short periods of time, these investors will demand more bail-in securities, driving down their yield, encouraging their issuance, and enabling banks to expand their balance sheets and loan portfolios. Short-term investors, aware that they are not in a position to be converted into a long-term equity investor, will try to preempt any change in the environment that suggests what was previously safe is no longer so. When a few read signs of trouble ahead and start to exit, others will quickly follow. There will be a herding and self-feeding effect across the asset class, putting scrutiny on good and bad banks alike as yields on cocos rocket across the board and rating agencies follow with widespread downgrades of the securities.

The full gamut of the alternatives to bail-in securities to mend the banks, revive the economy, and limit the cost to taxpayers, is outside the scope of this Policy Brief. My remit here is to show that bail-in securities are not the silver bullet. In practice, they will likely make matters worse. If more gold plating of bank capital is what is required, then this fool's gold will not do.

\section{REFERENCES}

Admati, A., P. M. DeMarzo, M. F. Hellwig, and P. Pfleiderer. 2011. Fallacies, Irrelevant Facts, and Myths in the Discussion of Capital Regulation: Why Bank Equity Is Not Expensive. Stanford Business School. Mimeo (April).

Avgouleas, A., and C. Goodhart. 2014. A Critical Evaluation Of Bail-In as a Bank Recapitalization Mechanism. International Macroeconomics Discussion Paper Series no. 10065 (July). London: Centre for Economic Policy Research.

Avgouleas, E., C. Goodhart, and D. Schoenmaker. 2013. Recovery and Resolution Plans as a Catalyst of Global Reform. Journal of Financial Stability 9: 210-18.

Basel Committee on Banking Supervision. 2011. Basel III: A Global Regulatory Framework For More Resilient Banks And Banking Systems (June). Basel.

Basel Committee on Banking Supervision. 2013. Regulatory Consistency Assessment Programme (Rcap)—Analysis of Risk-Weighted Assets for Credit Risk in the Banking Book (July). Basel.

Brunnermeier M., A. Crockett, C. Goodhart, A. Persaud, and Hyun Shin. 2009. The Fundamental Principles of Financial Regulation. Geneva Reports and the World Economy. ICMB/CEPR.

Calomiris, C., and R. Herring. 2012. Why And How To Design A Contingent Convertible Debt Requirement. In Rocky Times: New Perspectives On Financial Stability, ed. Y. Fuchita, R. Herring, and R. Litan. Washington: Brookings/NICMR Press.
Huertas, T. F. 2013. The Case for Bail-ins. In The Bank Recovery and Resolution Directive, ed. P. S. Kenadjian. De Gruyter. E-book.

Jaffee, D., and T. Russell. 1997. Catastrophe Insurance, Capital Markets And Uninsurable Risks. Journal of Risk and Insurance, no. 64: 205-30.

Persaud, A. 2000. Sending the Herd Off the Cliff Edge: The Disturbing Interaction Between Herding and Market-Sensitive Risk Management Practices. First Prize, Jacques de Larosiere Awards in Global Finance, IIF. Reprinted in BIS Papers. Available at www.bis.org/publ/bppdf/ bispap021.pdf.

Persaud, A. 2014. Reinventing Financial Regulation: Sanity Is Not Statistical. Springer (forthcoming).

Tucker, P. 2014. Regulatory Reform, Stability and Central Banking. Hutchins Center on Fiscal and Monetary Policy, Brookings Institution (January 18).

Ubide, Angel. 2008. Anatomy of a Modern Credit Crisis. Estabilidad Financiera, no. 14. Banco de Espana.

Warwick Commission. 2009. In Praise of an Unlevel Playing Field. Second Warwick Commission. University of Warwick.

This publication has been subjected to a prepublication peer review intended to ensure analytical quality. The views expressed are those of the author. This publication is part of the overall program of the Peterson Institute for International Economics, as endorsed by its Board of Directors, but it does not necessarily reflect the views of individual members of the Board or of the Institute's staff or management. The Institute is a private, nonprofit institution for rigorous, intellectually open, and honest study and discussion of international economic policy. Its purpose is to identify and analyze important issues to making globalization beneficial and sustainable for the people of the United States and the world and then to develop and communicate practical new approaches for dealing with them. The Institute is widely viewed as nonpartisan. Its work is funded by a highly diverse group of philanthropic foundations, private corporations, and interested individuals, as well as income on its capital fund. About 35 percent of the Institute's resources in its latest fiscal year were provided by contributors from outside the United States. A list of all financial supporters for the preceding year is posted at http://piie.com/supporters.cfm. 